\title{
SHIFTS IN URBAN PLANNING IN BELARUS? EXPERIENCE FROM BREST
}

\section{'Mikalai ULASIUK, ${ }^{2}$ Carola NEUGEBAUER}

\author{
'Department for Architecture and Territorial Development of Brest, Belarus \\ ${ }^{2}$ RWTH Aachen, Germany \\ 'ulasiuk@list.ru'2carola.neugebauer@rwth-aachen.de
}

\begin{abstract}
For long urban planning in post-Soviet Europe has missed scholarly attention in international urban studies, though it has changed fundamentally in the last three decades. The systemic upheaval in the early $1990 \mathrm{~s}$ questioned the basics of the Soviet mode of modernist urban planning. The latter relied on the quantification and predictability of people's needs, a strong state power and law enforcement through centralized planning, control and resources management (e.g. property). The latest since the 2010s, urban planning revives in the non-EU Eastern European states: 'New' urban planning instruments emerge; the so far sidelined citizens voice increasingly their interests; urban planning becomes an important arena for the contention and (re)production of both, the daily livelihood and the broader state-society relations often impregnated by (authoritarian) neoliberalism.

The paper takes up this general observation and explores the example of Brest in Belarus. It reviews the local planning approaches (i.e. instruments, contents and processes) in Brest and discusses how they blend in the current EU and post-Soviet debates. The paper concludes that the Brest planning (re)produces a mode of gradual post-Soviet transformation: It displays a surprising familiarity with EU leitmotifs (contents) and principles (e.g. law enforcement and state subsidies) for urban planning. At the same time, it confronts with the benefits and constraints of maintained Soviet planning traits, e.g. with the high professionalism and the centrality of state planning hierarchies. The case of Brest reveals how local stakeholder alliances co-produce new opportunities for local urban planning and thus for an incremental change in Belarusian planning by engaging with the central state institutions as well as with the international debates.
\end{abstract}

Key words: urban planning, planning approaches, planning instruments, Brest, Belarus.

DOI: https://doi.org/10.17721/2413-7154/2021.85.49-61

UDC: $911.3: 711.4$

Received: March 2, 2021.

Accepted: March 24, 2021.

\section{ЧИ ЗМІНЮЄТЬСЯ МІСЬКЕ ПЛАНУВАННЯ В БІЛОРУСІ? ДОСВІД БРЕСТА}

\author{
'Мікалай УЛАСЮК, ${ }^{2}$ Карола НОЙГЕБАУЕР \\ 'Управління архітектури і територіального розвитку Бреста, Білорусь \\ ${ }^{2}$ Рейнсько-Вестфальський технічний університет Аахена, Німеччина \\ 'ulasiuk@list.ru²carola.neugebauer@rwth-aachen.de
}

\begin{abstract}
Анотація: Аналіз міжнародних урбаністичних досліджень свідчить про недостатню увагу фахівців до проблематики міського планування в пострадянських країнах Європи, незважаючи на принципові зрушення останніх трьох десятиліть. Системні зрушення на початку 1990-х років поставили під сумнів основи радянського модерністського підходу до міського планування, що спирався на кількісні методи оцінки людських потреб та їх передбачуваність, потужну державну вертикаль та правове регулювання за допомогою централізованого планування, контролю та управління ресурсами (наприклад, майном). Проте, найпізніше в 2010-х роках, відбувається зміна містобудівних підходів в країнах Східної Європи, що не входять до складу ЄС. Зокрема, з'являються "нові" інструменти планування; громадяни, раніше відсторонені від містобудівного процесу, дедалі частіше висловлюють свої інтереси; міське планування стає важливою ареною для конкуренції та репродукування як повсякденних практик, так і більш широких відносин між державою та суспільством, часто просякнутих (авторитарним) неолібералізмом.

Ці загальні тенденції та зрушення розглянуто в статті на прикладі міста Брест в Білорусі крізь призму місцевих підходів до міського планування (його зміст, інструменти, й процеси) та їх зв'язку із сучасними тенденціями в галузі міського планування в країнах $Є С$ та пострадянського простору. Зроблено висновок, що міське планування в Бресті слідує моделі поступової пострадянської трансформації. 3 однієї сторони, спостерігається вражаюча подібність до лейтмотивів (змістів) та принципів міського планування в країнах ЄС (наприклад, в частині законодавчих інструментів та державних субсидій). Водночас, міське планування в Бресті відзначається консервативними рисами та віддзеркалює переваги й недоліки радянських містобудівних підходів. Зокрема, високий рівень збереженості професійної школи фахівців 3 міського планування співіснує 3 високим рівнем державної централізації містобудівного процесу. Кейс Бреста показує, як альянси місцевих зацікавлених сторін створюють нові можливості для міського планування на локальному рівні, та розкриває потенціал для поступових змін парадигми міського планування в Білорусі, що може бути реалізований шляхом поєднання досвіду функціонування центральних державних установ та міжнародного дискурсу.
\end{abstract}

Ключові слова: міське планування, підходи до планування, планувальні інструменти, Брест, Білорусь. 


\section{Introduction}

For long urban planning in post-Soviet Europe has missed scholarly attention, though it has changed fundamentally during the last three decades. The systemic upheaval in the early 1990s questioned the basics of the Soviet mode of modernist urban planning. The latter relied on the quantification and predictability of people's needs (Healey, 1997) as well as on strong state power and law enforcement through centralized planning, control, and resources management (e.g. property). With the collapse of the Soviet Union, in most of the successor states the politics and private business relegated public planning to the backseats of 'city making'. Until the early 2000s, the state property was mainly privatized, new planning codes were approved and urban planning was decentralized, i.e. declared an affair of local municipalities.

Since the 2010s, urban planning revives in these Eastern European, non-EU states. We witness local experiments with 'new' instruments of urban planning such as the rise of international design competitions (e.g. Dixon, 2010; Trumbull, 2010) and strategic master planning (cf. Semenov et al., 2020; Appenzeller, 2017). New stakeholders interfere increasingly in planning: citizens mobilize against unloved construction projects (e.g. Semenov, 2020) and urban activism that relates to planning evolves vibrantly in terms of scope and quality (Darieva et al., 2020). The consciousness and interest in urban development and planning - its failures and potentials - grows. In many countries of the former Soviet Union, urban planning became an important arena for the contention and (re)production of both, the daily livelihood and the broader statesociety relations often impregnated by (authoritarian) neoliberalism (e.g. Neugebauer et al., 2015; Darieva et al., 2020; Neugebauer et al., 2021). Urban planning decides upon future land-uses and thus concerns and involves state executives, politicians, professional experts, citizens, and private entrepreneurs.

The city of Brest in Belarus offers an intriguing case to explore and question these prevailing observations of post-Soviet urban planning in Eastern Europe. As an 'ordinary city' (Robinson, 2006) - neither a capital nor a metropolis - Brest has been broadly excluded from scholarly attention, so far. Moreover, it is located in Belarus as a country that is often considered as stiff and 'iron clinging to the Soviet past' and thus of little interest for many. Little would change; what shall we learn from Brest/ Belarus?

This paper takes up this question and aims in particular at a review of the current urban planning approaches (i.e. instruments, contents, and processes) in Brest, Belarus. We ask for the recent local developments in planning and how they blend in the current EuropeanCentral EU-European and post-Soviet European - shifts and pleadings in urban planning and development. We finally argue that the urban planning in Brest (re)produces a trajectory of gradual post-Soviet transformation. The planning stands out in the current post-Soviet realm marked by abrupt systemic breaks and a slow recovery of planning only. The Belarusian case rather displays surprising familiarity with EU- planning approaches in terms of leitmotifs (contents) and principles (e.g. law enforcement and state subsidies); it confronts with the benefits and constraints of some maintained Soviet planning traits, e.g. with the high professionalism and the centrality of state planning hierarchies. The case of Brest finally also reveals how local stakeholder alliances co-produced new opportunities for local urban planning and thus for an incremental change in Belarusian planning by engaging with the central state institutions as well as with international debates.

The paper on hand is an endeavor of two colleagues with different bodies of knowledge - the insights and experiences of the first author who is currently a chief architect in the city of Brest, and the ideas of the second author researching urban planning and transformation in post-Soviet cities for a couple of years. We attempted to balance the perspectives of an involved practitioner and an external foreign scholar.

The paper is structured as follows: after a brief look at the new 'quality turn' in Belarusian planning debate, we focus on the toolbox of planning in Brest, which further relies on the statutory land-use planning, but recently engages with informal, strategic planning instruments as well. In doing so, analytical attention is given to the contents (leitmotifs), processes, and stakeholders in planning. We also include short references to current planning experiences in Central and PostSoviet Europe. We summarize our key arguments in the last part of the paper.

Re-orienting the emphasis: The 'qualitative turn' in planning discourse

In today's globalized world, cities compete for economic competitiveness and human resources. Soft conditions - such as urban amenities of high quality have gained importance for urban development (e.g. Musterd et al., 2010). This message has infiltrated into the current Belarusian urban planning debates, too: which city is better, where there are more opportunities - young, energetic, and creative people will live there and leave their taxes, whether they will be an IT programmer, freelancer, musician or businessman. Also, the modern demands of the inhabitants of our cities, the concept of a comfortable urban environment (safe, green, environmentally friendly, etc.) raise the level for decision-makers and urban planners.

The recent discussions about the remodeling of the "microrayony" may testify this 'turn' towards new qualitative thinking in urban planning: Lately, there has been a lot of talk about creating a comfortable environment in micro-districts-new buildings and in the satellite cities of large cities. Attention was repeatedly focused on the need for:

- creation of low-rise building areas, implementation of pilot projects for the integrated development of land plots with low-rise residential buildings in big cities;

- solving problems of greening during the construction of new neighborhoods.

Yet so far, the quantitative approach in urban planning still prevails in Belorussian practice. It 
orients urban planning towards a sectoral and linear understanding of economic growth, where hard location conditions matter only (such as transport infrastructures etc.); everything is aimed at economic growth (i.e. sectoral government of the city). Thus, in the modern model for assessing the effectiveness of the development of cities in Belarus, a quantitative approach prevails: the effectiveness of development is measured by the built square meters of housing, kilometers of roads and streets, and the percentage of landscaping. These indicators are markers in the final republican reports, where the city authorities are trying to achieve the necessary results: more city - more residents, more roads and streets. But in general, this affects the city and the quality of life: a large number of monotonous buildings using large-panel housing construction, social infrastructure that does not keep up with housing and insufficient landscaping. The norms and parameters of the red lines themselves, the reserve corridors of engineering networks for the future for the streets indicate that we do not count our own funds.

In this broader context of Belarussian planning debates and actual practice, the city of Brest did an attempt of re-orientation. In the last four years, the city has undertaken several steps towards a more qualityoriented urban planning. It opts today for the territorial/ environmental government of the city, where the aim of urban management constitutes the reduction of the operating costs of maintaining the city, increasing the economic, socio-cultural, and ecological benefits of the urban environment by improving its quality, preserving monuments, increasing diversity, greening. Though economic reasoning (i.e. urban economic growth and competitiveness) still impregnates planning discourses in Belarus and Brest as the predominant basic rationale, the way, how to approach, analyze and develop the city and urban fabric is going to change: It turns towards the quality of urban environments (livability), planning and design. New topics emerge in urban planning, such as the 'Green and Circular City' (cf. Ulasiuk, 2019), which require a quantitative and qualitative, integrated and flexible thinking. This new agenda of Brest's urban planning - by the way - picks up some key issues of the present EU agenda for spatial development (Territorial Agenda 2030), as we will show below.

An evolving toolbox of instruments? The obduracy of statutory land-use planning

To this end, the urban planning department of Architectural Design and Drawing and Urban Development initiated - with the help of the architecture department of Brest Technical University and in alliance with the mayor and the city council of Brest - to supplement the toolbox of urban planning instruments. Today, it includes three main blocks: the informal strategic planning instruments - urban strategies and concepts; the statutory and formalized planning instruments - Urban planning documents, as well as informal tools of competitive urban planning and development - such as Architectural competitions and public-private-partnership contracts (e.g. auctions, Fig. 1.).

The instruments of statutory land-use planning are deeply rooted in the Central European and Soviet planning traditions. They form a hierarchical system with the General Plan (city-wide land-use and zoning plan) on top and the detailed land-use plans, e.g. detailed

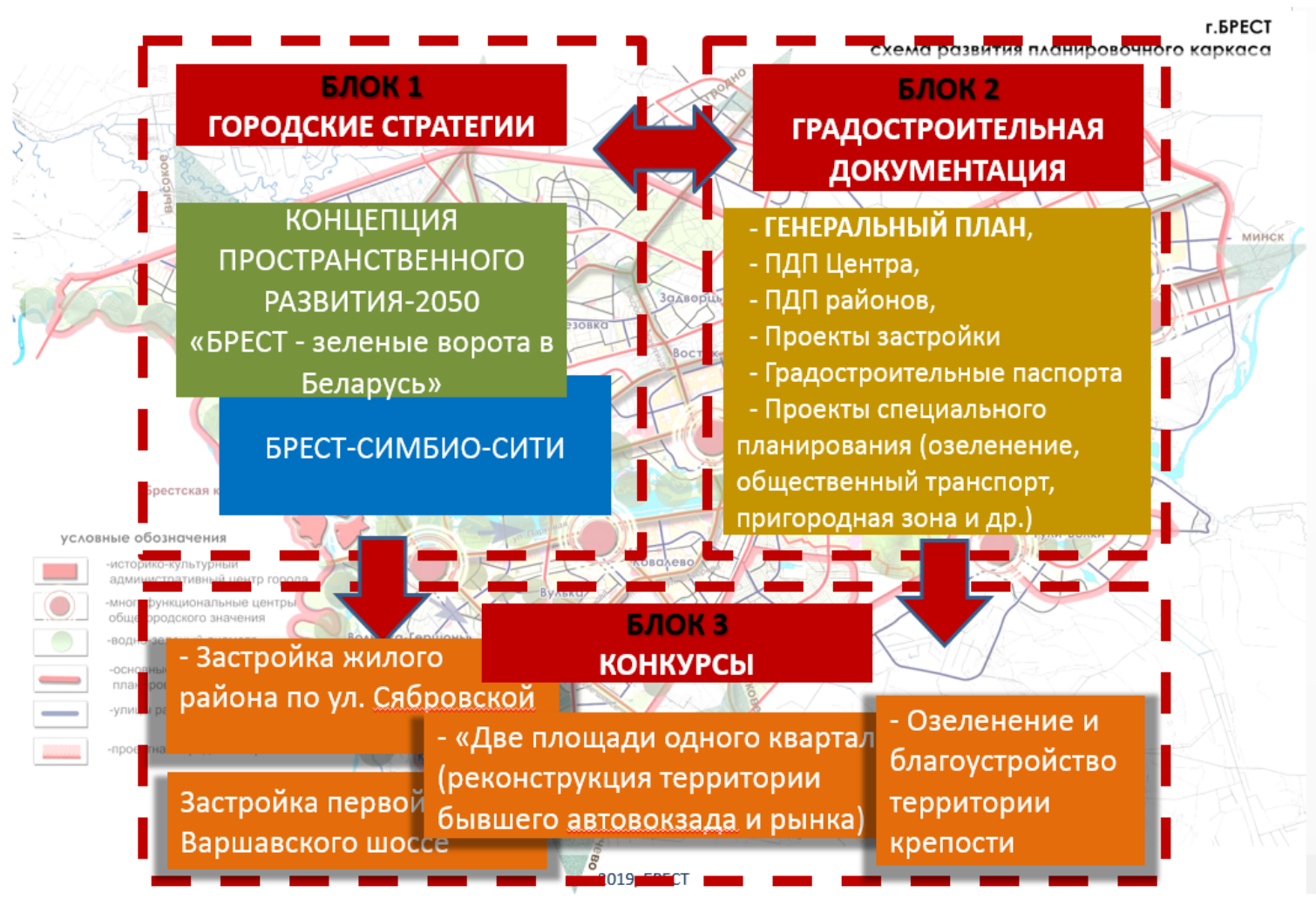

Fig. 1. Brest - modern city planning and development 
plan of the residential area etc. As backbone of the urban development regulation in many European and postSoviet countries, the statutory planning instruments share a set of features:

- The land-use plans largely answer the questions of how much and where to build. They spatially organize the different, often contradicting land-use interests and thus constitute the key access point to foster a sustainable mixture of urban land-uses.

- The instruments' special importance stems from its unique power to bind legally all the urban stakeholders. The statutory land-use plans can serve as 'hard causes' for court trials. Often, it is mandatory to elaborate such land-use plans as basis for any construction permit.

Moreover, law formalizes the process of statutory land-use planning. It defines and guarantees the different access points of urban stakeholders to planning, at least ideally.

Beyond these joint similarities, there are context-specific differences. In Belarus, for example, approaches to the design of general plans have retained much in common with the Soviet past. Still today, the master plan is the main document in the field of urban planning, intended to a greater extent for a narrow circle of specialists - managers, architects, and land surveyors. Differently than in Germany and decentralized post-Soviet countries, the General Plan of major regional cities in Belarus is not requested, elaborated, and adopted at the municipal level, but ordered by the National Ministry for Architecture and drafted by the National Institute for Urban Development of the Belarusian Research and Design Institute for regional and urban planning UE. At the local level, the General plan is just checked by the mayor's office, presented at the public hearing, and discussed by the Planning Committee. Only the Detailed plans are ordered by the municipality and local authorities. The architecture department forms the design assignment. The town planning council is reviewing the project. And then it undergoes a state examination. In this process of detailed land-use planning, local MPs are not involved. This brief look at statutory planning reveals that the Belarusian urban planning system has maintained a high degree of centralized state power and professionalism (or 'professional bureaucracy'). We witness only gradual steps towards municipal independence in planning - e.g. the local responsibility of detailed planning - in contrast to the harsh shifts towards decentralization in many other post-Soviet planning systems after 1991.

Apart from that, current debates regarding the reform of statutory land-use planning center around the shared post-Soviet concern of lacking effectiveness. The majority of master plans run the risk of remaining only on paper. Attempts to respond to this problem seem to favor a neoliberal approach. The belief is widespread that the flexibilization of the General Planning processes or the relaxation of its binding power for land uses (e.g. the suspension of obligation for planning) would 'solve' the problem of missing effectiveness. However, the defendant's aspect of ineffectiveness may be quite specific. While Belarusian urban planners complain about the static and inflexible nature of the General Plan - namely the difficulties of plan amendments to capture flexibly private investments, the citizens in Russia are suffering explicitly from the opposite, namely from the investment-driven flexibility of General Planning that 'legalizes' the economic encroachment of their urban livelihoods (cf. Neugebauer et al., 2021). Thus, though reforms in the sphere of urban planning are needed, they have to balance critically the specific local needs.

Against this backdrop and in favor of the aforementioned 'qualitative turn', the urban planning in Brest decided to qualify their statutory land-use planning documents by the means of a sufficient socioeconomic rationale instead of questioning the General Plan in principle. A unique experience for Belarus, Brest managed to combine theoretical urban planning analysis in urban planning documentation approved by the Head of State and the city, together with the request and wishes of city residents that were carried out in the context of new strategic urban planning processes in Brest. As the only one in Belarus ${ }^{2}$ and probably one of very few other post-Soviet cities (cf. Semenov et al., 2020), the local authorities of Brest managed to integrate the key messages of the strategic urban planning into the statutory landuse planning, i.e. into the development of urban planning documentation.

When in 2017 Urban Development of the Belarusian Research and Design Institute of Regional and Urban Planning UE began the development of the Master Plan of the city (Fig. 2) and the Detailed Regeneration Plan of the Historical Center (Fig. 3), the design assignment included the developments of the spatial development strategy-2050 and the concept of Symbio City (Fig. 1). Consequently, in 2018, at the city sessions of deputies, the concept of Symbio City was approved, in 2019 - the Spatial Development Strategy for Brest-2050. In 2019, the General Plan of the regional center and a detailed plan of the historical center of Brest were approved. The city received a roadmap for further quality development. Through the integration in the statutory land-use planning, the informal strategic planning contents gained legally binding power.

\section{The testing of informal planning instruments}

The introduction of informal planning enabled the (re)discovery of two important features in urban planning: First, the informal planning instruments (re) vived the comprehensive and integrated view of the city and sensitized for an incremental (step-by-step) implementation of urban planning. New leitmotifs for urban planning and design popped up (such as the

\footnotetext{
${ }^{1}$ E.g. changes in the master plan are quite expensive and time-consuming work (it is necessary to coordinate with more than 20 ministries and various departments and pass several examinations. Therefore, only the master plan of Minsk is often corrected.

${ }^{2}$ Following Brest, similar strategies were developed for small towns of Belarus: Polotsk, Novopolotsk, and Novogrudok within the framework of the UN project "Green Urban Development" with the participation of experts from the Department of Urban Development of the Belarusian National Technical University and MLA + experts, but in Brest, it was possible to approve a master plan in conjunction with the strategy.
} 


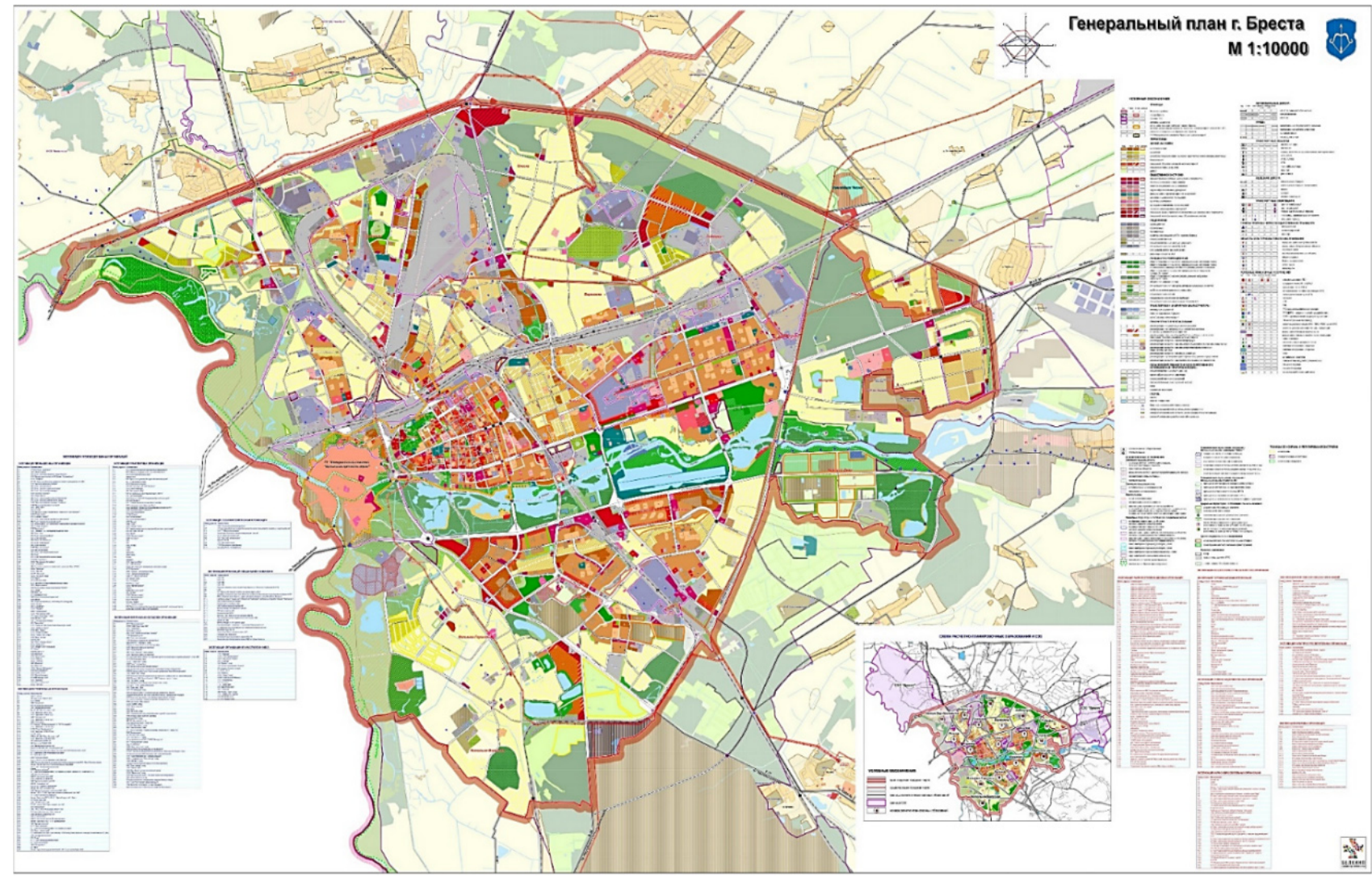

Fig. 2. Brest . General Plan. 2019

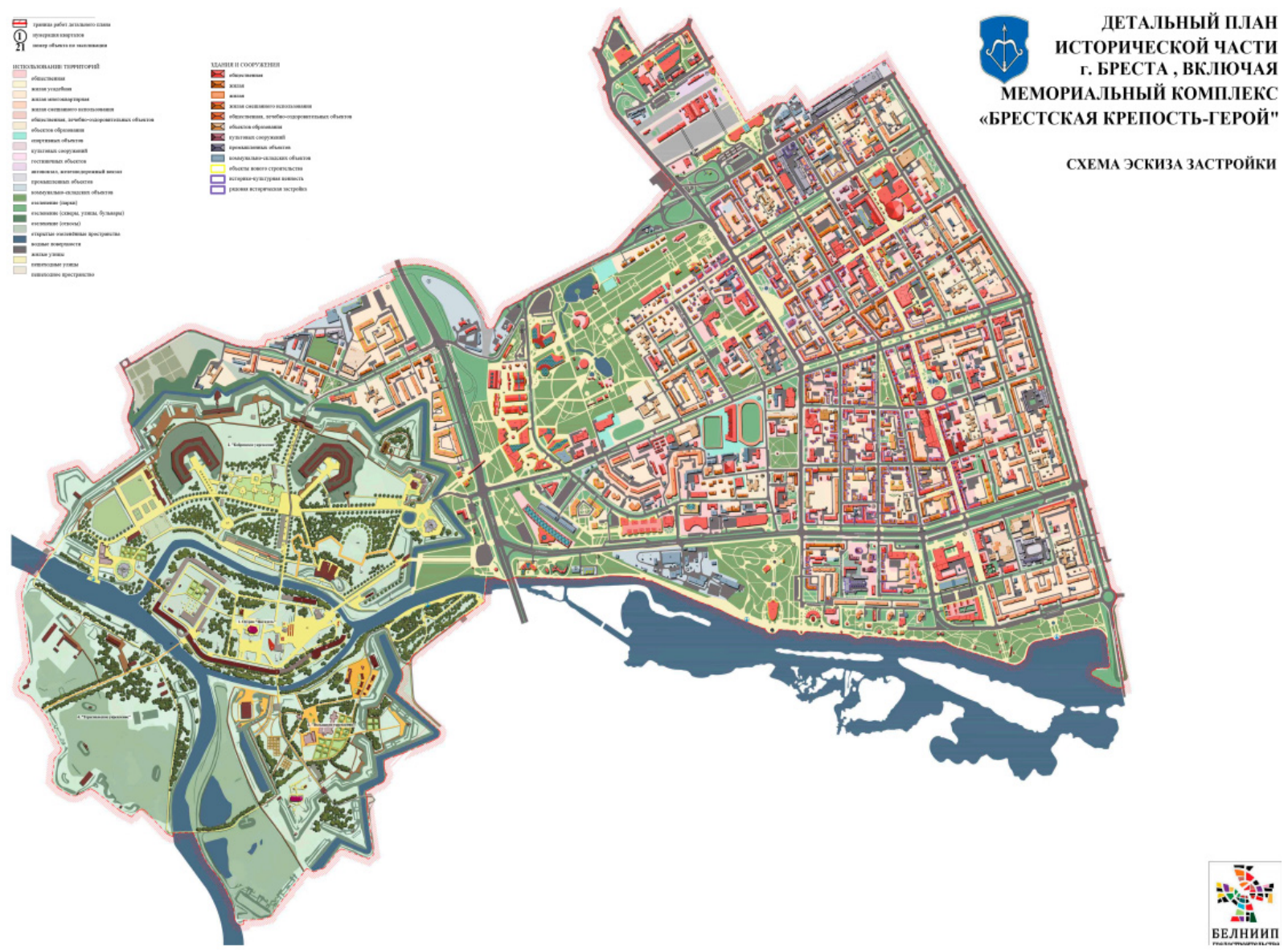

Fig. 3. Brest. Detailed Plan of the Historic Center 
"compact city" and the "symbio | circular city") that may help to break down entrenched boundaries of sectoral thinking in public authorities and encourage joint forces for steps of implementation. Secondly, the informal planning instruments offered a testing ground for new stakeholder cooperation that goes beyond the public authorities due to their little (or missing) legal formalization. At this stage, we can't assess if and how these experiences will nest in Brest and bring up new co-operative planning routines in the long term. Nevertheless, we will have a closer look at these new or revived experiences next.

The Symbio City Concepts constitute the initial project in the broader endeavour of strategic planning in Brest. Today, the concept is an integral part of the Spatial Development Strategy (Fig. 1). The occasion for the Symbio City concept was the inclusion of Brest into the UNDP Green Cities project by the Resolution of the Council of Ministers and the National Action Plan for the Development of a Green Economy in Belarus and the Covenant of Mayors of Brest. The Symbio City Concept is the result of joint work of Belarusian, European expertsurbanists and city authorities within the framework ${ }^{3}$.

The concept is a model of sustainable urban development, which is based on the interaction (synergy) of seven urban systems: climate, transport, architecture and landscape, waste management, water supply and sanitation, urban management (Fig. 4). The ecological, energy-efficient technologies used in the model are well known to specialists in themselves and each separately. A synergistic effect arises when the branches of the municipal economy that exist separately and solve their problems locally begin to solve them together. Thus, the Symbio City concept requires coordinated action within several local urban systems and local experts within the public authorities (architecture and landscape; energy and climate; urban mobility; waste; water supply and sanitation; education and culture). If this concept starts to be implemented, the city will receive new opportunities for the development of an integrated sustainable urban system.

In the city executive committee ${ }^{4}$, a group of experts is being created in areas that are united by a common environmental goal. For each of the seven directions of the concept, goals for the future were determined - until 2020, 2035 and 2050. The city of Brest, which joined the Covenant of Mayors on Climate and Energy in 2015, due to the concept "Brest: Symbio City 2050" plans to achieve a reduction in $\mathrm{CO}_{2}$ emissions of up to $20 \%$ compared to 2010, and to implement the "Green City" concept.

The Symbio City concept has been followed by the more comprehensive Spatial Development Strategy for the whole Brest and all aspects of urban space development. The strategy consists of the "BREST 2050" vision, targets and ten areas for future urban development (Fig. 5) $)^{5}$. The strategy points at topics and leitmotifs for urban development, which display the 'new' emphasis on livable urban environments and its interlinkage to urban economy; the chosen leitmotifs also resonate with the current key concepts of EU- Europe, for example:

- the Brest 'Compact City Strategy' is very close to the European Union's urban design leitmotif outlined in the Leipzig Charter (EU Council 2020);

- the "green-frame, water-diameter strategy (Central City Park)' links to the green-and-blue infrastructure thinking of the EU territorial Agenda 2030 (Territorial Agenda 2030);

- the "Symbio City concept" resonates with the European Union's aim of circular urban economies (Territorial Agenda 2030),

- the Growth Zone strategy (technopark, industrial and IT clusters, service sector) links to the aforementioned, well-established debate on service and knowledge economies;

- the "residential area strategy" includes both, the new development areas and an energy efficiency module as well as the renewal of existing residential areas, which links to the European Union's core idea of stock-oriented urban renewal planning (EU Council 2020).

Beyond these concepts and leitmotifs, an important feature of Strategic Plans - and thus of the Strategy for Spatial Development in Brest too constitutes the orientation to implementation: The Brest Strategy defines the list of priority and long-term projects, targets, implementation mechanisms and performance indicators ${ }^{6}$.

Some projects have already been launched in Brest due to the directions of the approved strategy. For example, the reconstruction and improvement of the embankment of the Mukhavets River are in full swing. Various public organizations, such as "Time of the Earth", "BREST FOR BICYCLE", as well as residents are actively involved in landscaping the city. The total length of bike paths has been increased. Moreover, several measures significantly increased the level of the greening of the city: the historical park "City Garden" was reconstructed, green areas are being improved in the existing micro-districts (Park "Mira", a square in Yuzhny, a square along Salnikov (SouthWest microdistrict 3) and new parks and squares are being laid (park of the 1000th anniversary, a square on Volgogradskaya street, a square of Brest Bible, Pushkin square, a square in the area of Partyzanski avenue).

In the process of plan implementation, the city of

\footnotetext{
${ }^{3}$ Symbio City 2050 is one of the activities of the National Action Plan for the Development of a Green Economy in Belarus until 2020 (approved by the Resolution of the Council of Ministers of the Republic of Belarus No. 1061 on December 21, 2016). Besides, on October 26, 2015, Brest joined the European Covenant of Mayors movement and committed itself to mobilize all resources and human potential to reduce greenhouse gas emissions by at least $20 \%$ compared to the base year.

${ }^{4}$ i. e. the executive committee of the city Council of Deputies.

${ }^{5}$ Please note: Another important document - that we don't discuss in detail here - represents the strategy of socio-economic development, which identifies the necessary resources and sources of funding, estimates the results in advance, but does not address the issues of spatial development and the creation of a comfortable urban environment.

${ }^{6}$ In doing so, the assessment system consists of a number of indicators that are responsible for a certain type of urban space and reflect the degree of environmental quality for each of the criteria.
} 
Brest also uses tools of competitive urban planning (cf. Fig. 6), i.e. international design competitions and forms of public-private-partnerships. Examples are:

- The results of the international architectural competition for the creation of a new public space "Two squares of one quarter" on the site of the former bus station have been summed up.
- Work is underway to change the principles of building residential areas: a competition was held for the concept of building blocks of a residential area with the reconstruction of Fort No. 4 on Syabrovskaya street (Fig. 12), detailed planning projects (South-West microdistrict 1), Yuzhny, Brest Venice; all new districts have a recognizable design

\section{СИСТЕМНЫЙ ПОДХОД К ГОРОДУ}
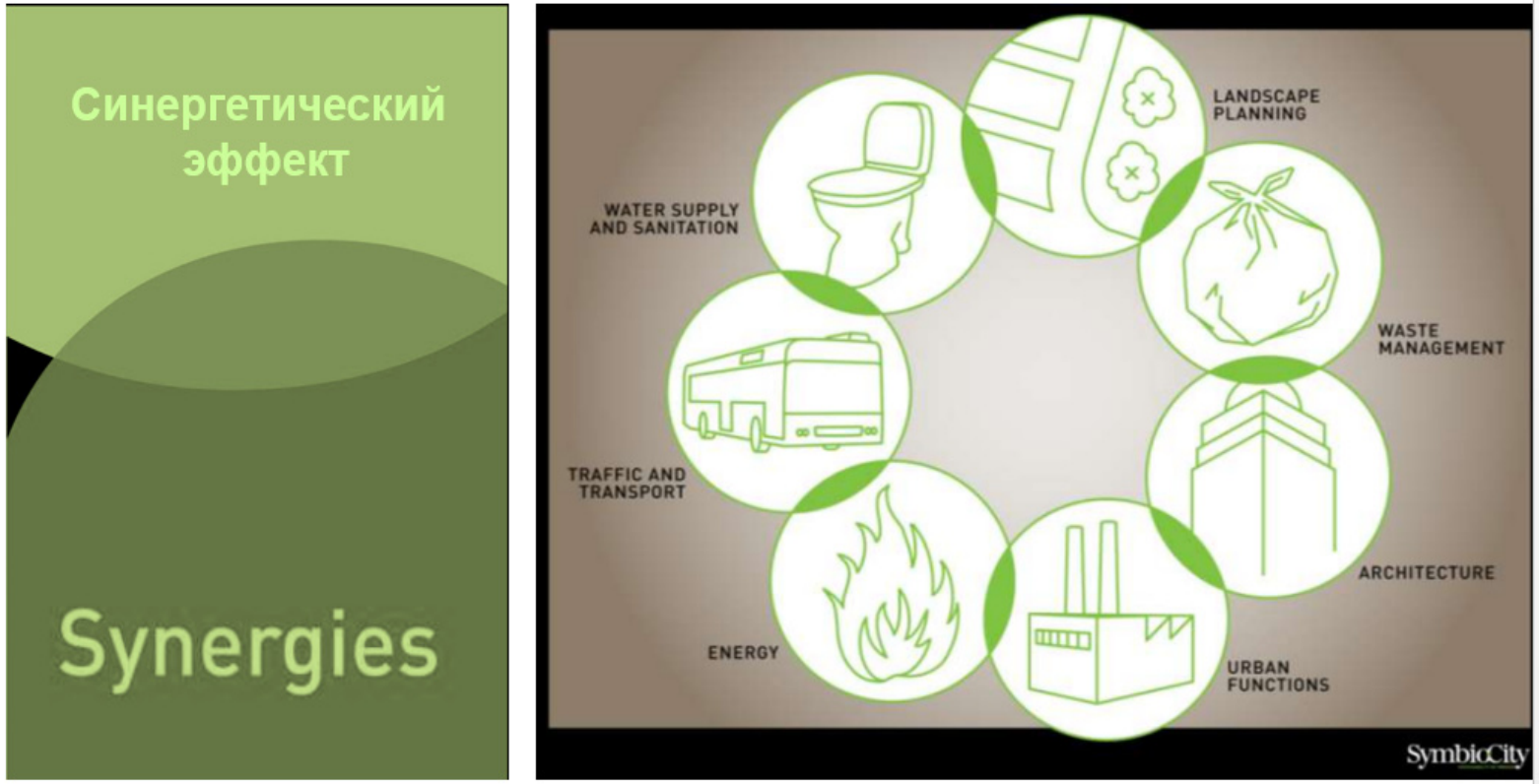

Fig. 4. Symbio City . A systematic approach to the city

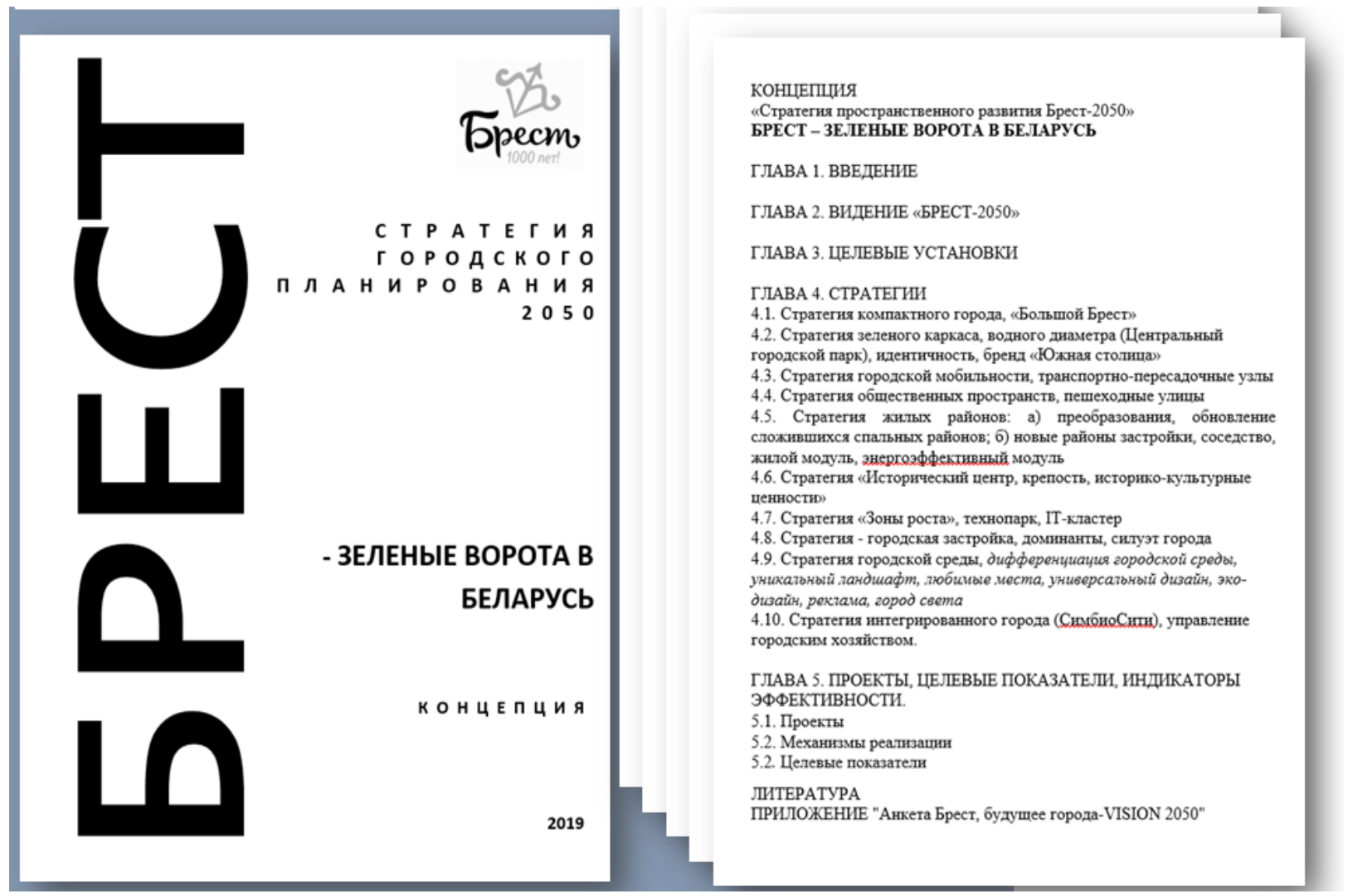

Fig. 5. Spatial development strategy - 2050. Brest is the green gate to Belarus 
code, which makes it easy to identify the district and navigate the city.

- Competition for the concept of landscaping the Brest Fortress.

- In Brest, the existing technopark, located in the former industrial zone, is being reconstructed, and an investment agreement has been signed for the construction of the first stage of a modern IT cluster in the area of a technical university.

The urban planning department of Brest together with its local partners (ie the city housing and communal services, Zelenstroy, city council, Brest waste recycling plant, traffic police, city transport department, public organizations and other city services) runs for the further, successful implementation of the Spatial Strategy and thus for a more quality-oriented urban planning and development in Brest. Therefore, a couple of hurdles are still to be overcome, for example:

- the formation of the city budget in accordance with the priorities of the strategy with the use of expert assessments in the systematization and ranking of projects. Though Brest allowed the administration itself to define a roadmap for the development of the city and understand the priorities for transforming the quality of the city's development thanks to the Strategic Planning process. they are determined centrally in accordance with the adjusted republican indicators. So far, the aforementioned projects are financed by city budget, regional and republican level programs, private investments;

- development of urban planning projects (RAP, special planning projects, urban planning passports, strategies), since there are not enough international competitions for the development of territories. In this vein, we also need to build professional communities and experts to evaluate urban development projects;

- creation of a structure - PMC or department (agency for the implementation of urban strategies) for the formulation, development of urban projects, strategies and their promotion;

- establishing a dialogue with the city community, public organizations, involving them in the implementation of city projects (e.g. the creation of an Information Center in the city for presentations of urban planning projects) and more active participation of the deputy corps.

Finally, this brief look at the urban planning instruments in Brest reveals that although the Belarussian planning legislation and statutory planning practices have not changed much for the last three decades, the informal approaches to urban planning are vibrantly evolving today. Strategic Planning seems to foster both, the definition of 'new' topics and leitmotifs in urban planning and development that are very close to the professional ideas in EU-Europe, as well as a broader understanding of communication and cooperation in planning, i.e. the cross-sectoral coordination within the public authorities and the collaboration with the local urban society.

\section{Processes and stakeholders in urban planning}

In line with this last note, the elaboration of the Brest Strategy of Spatial Development constituted a complex process that involved various stakeholders and interests. The Strategic planning process benefited from, over time, the availability of resources for the 1000th anniversary of the city and the availability of specialists and managers willing to promote urban strategies. There were:

- the initiative of the chief architect of the city with the support of the mayor and the city council of deputies;

- creation of a working group of specialists at the city executive committee;

- the activity of public organizations (cycling communities, greens, the society of the disabled, students-architects);

- participation of Brest in the Covenant of Mayors and participation in the EU grant "Green Cities" (see Symbio City).

The Strategic Planning process included a sociological survey, work with international ${ }^{7}$ and local experts, specialists of the Urban Development of the Belarusian Research and Design Institute of Regional and Urban Planning UE, investors ${ }^{8}$, public organizations and local authorities, assessment of strengths and weaknesses - SWOT (C) -analysis.

The active involvement of the citizens and civil society in the planning process and beyond the mandatory public hearing constituted a novelty in Brest. The citizens informed the planning process: They mattered when it was to figure out the strengths and weaknesses of the city, and they informed the leitmotif-process ("Vision"). To this end, in 2016, the Department of Architecture and Urban Planning on the basis of the Technical University held a number of round tables on the topic: "Spatial Development Strategy-2050. Vision", a sociological survey is being conducted with more than 600 respondents on the subject: what do you like in the city, and what not to like, how would you like to see the city in the future? (Fig. 7). In the information centre of the city executive committee (i.e. in the city hall), questionnaires were proposed for polling the opinions of residents, two Google maps $2.5 \times 2.5$ meters with a plan of the whole city and the historical centre was posted. It is offered the opportunity to designate stickers of different colours on the map "good" and "bad" places in the city in the opinion of the residents

\footnotetext{
${ }^{7}$ e.g. MLA+ as one of the international key agencies promoting and doing strategic plans for many cities in the FSU; further experts such as M. Stepura,Ya. Golubeva, A. Golovin, and Stockholm City Administration (Sweeden).

${ }^{8}$ All developers of the city, both foreign and local, were invited. For example, Savushkin Product, that has built a modern park in the city and holds festivals there.

${ }^{9}$ The participants were architects and teachers of the Faculty of Architecture from Minsk and Brest, the Architecture Department of the City Executive Committee, public organizations, including, of course, the townspeople, designers, the Union of Architects.
} 


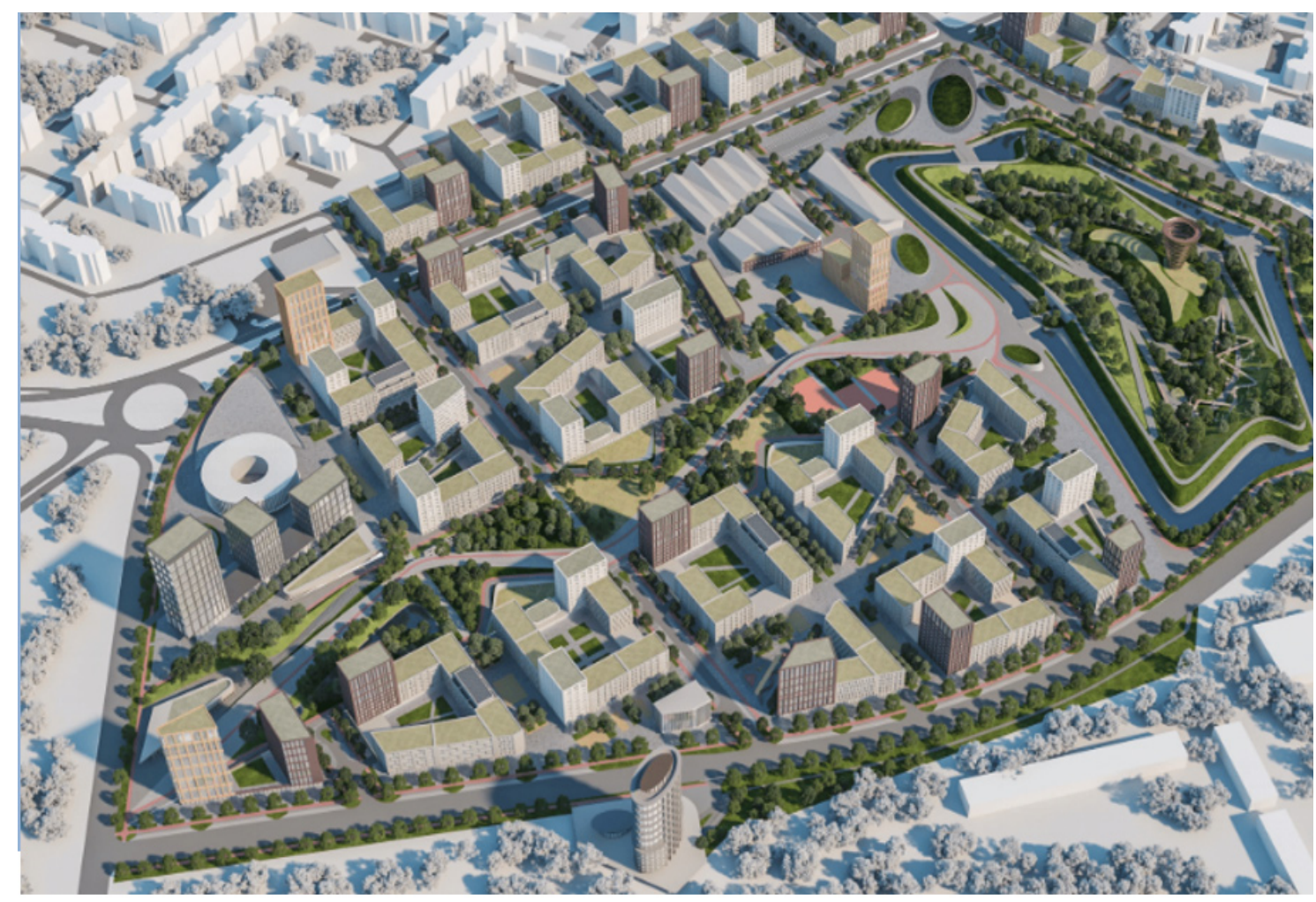

Fig. 6. Competition for the development of a residential area - IV Fort

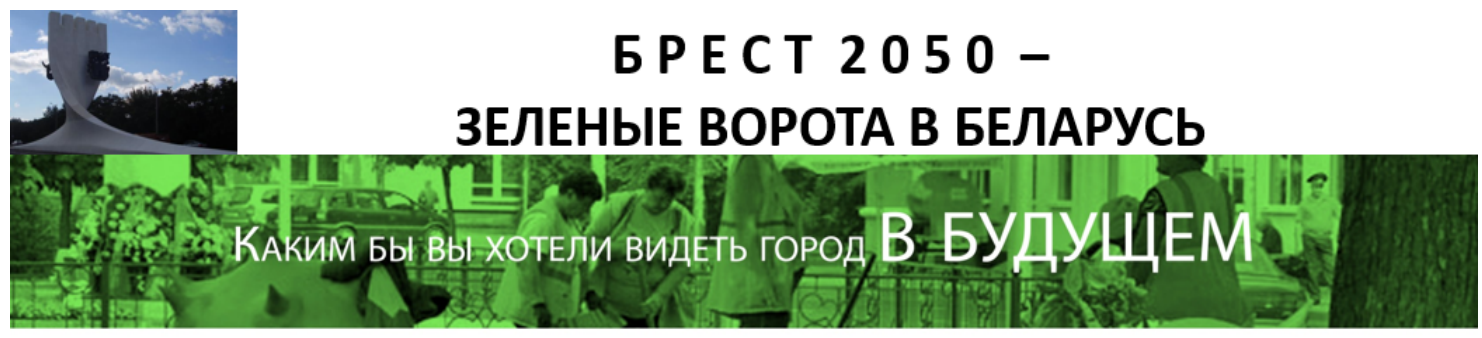

ПЕШЕХОДНЫЙ

ДРУЖЕСТВЕННЫЙ

\section{СОВРЕМЕННЫЙ}

\section{ЕВРОПЕЙСКИЙ}

НОчной

$$
\text { ЗЕЛЁНЫЙ }
$$

СПОРТИВНЫЙ

ГОСТЕПРИИМНЫЙ

РЕЧнОЙ

ПРОМЫШЛЕННЫЙ

НАБЕРЕЖНАЯ

ЮЖНАЯ СТОЛИЦА БЕЛАРУСИ

\section{БЛАГОУСТРОЕННЫЙ}

ТУРИСТИЧЕСКИЙ 
themselves, numbered stickers can be explained in a separate record book.

The final strategy for spatial development is adopted by the local council of deputies, discussed with city residents in the course of a public hearing. Apart from the citizens' feedback, the whole planning process benefited importantly from the correct, positive dynamics among the availability of experts and a team of professionals in urban development.

In the case of Brest, the strategic planning process proved to work out as a valuable testing ground for new approaches of cross-sectoral cooperation within the local public authorities and beyond this realm. It activated the usually more passive range of stakeholders and alliances in Belarusian urban planning, namely the local citizens and public organizations as well as the local politics in person of the mayor and deputies. Moreover, international experts (e.g. MLA + , GIZ / IBB, Stockholm City Hall) and regional experts from science (e.g. the Technical University of Brest) have been actively involved. In these respects, the informal planning process stands out from the formalized processes of statutory land-use planning.

Looking at the routines of statutory land-use in Brest, Belarus, we observe in particular:

The marginal, not an active enough role of the local deputies in urban planning

Differently than in EU countries as well as in Ukraine and Russia (cf. Neugebauer et al., 2021; Neugebauer et al., 2020), the Belarusian legislation grants few rights to the city council in statutory land-use planning only: The deputies neither initiate land-use planning processes nor approve the planning documents. The nexus between statutory land-use planning and the local system of parliamentary democracy is weak. Nevertheless, the deputies own opportunities in urban planning, e.g. as members of the Special Urban Development Commission. They are also the directly elected representatives of the citizens and resolve individual private requests and requests of citizens that sometimes touches the field of planning. In general, however, the deputies should be intermediaries between the authorities and residents, participate in the formation of a request from residents and transfer it to the city government; they should engage with urban planning issues and the debates for the good of the citizens. The new aforementioned processes of strategic planning have been the first step in this direction.

The formal upgrading, but informal containment of citizens' voices in planning. This observation leads to the actual practice of citizen participation in Belarus
Since 2012, it has become mandatory to conduct a public discussion of urban planning documentation. For urban planning and construction projects, there are two types of public consultation, and the most important is the public consultation regulation approved by the Ministry of Architecture and Construction $^{10}$. It is carried out when the general plan of the city is being designed, a detailed plan of a residential area, and when individual objects are being designed (as a rule, compaction) in the absence of a detailed plan - the architectural concept of the object. The city executive committee advertises on the website and in the newspaper, then the project is presented at the mayor's office. The comments are sent to the city hall within a month, and then the town planning council considers them on the merits and decides whether to take the comments into account or not. The results are posted on the website of the city executive committee.

So far, however, the citizens' voices in urban planning are still soft. Some reasons are (1) the missing knowledge among citizens - e.g. due to the existing specifics of these projects, the procedure is not sufficiently discussed and is not clear enough for ordinary citizens, (2) the lacking skills among the representatives of public authorities - e.g. a missing language of dialogue, lack of professional experts on urban planning and insufficient culture and practice of their implementation, and (3) a missing general interest in listening to the citizens, e.g. among local deputies. Thus, even though there are examples where residents influence the results of local planning and their opinions are taken into account ${ }^{11}$, citizen participation remains a testing field in Belarusian urban planning.

The tension between policies of deregulation in planning in favour of private investments and the regulatory inertia of planning bureaucracy.

In Belarus, there are two forms of interaction between the developer and the authorities: an auction and an investment project ${ }^{12}$. In the latter, the land is provided free of charge, but there are rather strict restrictions on the timing of construction and investments. Sometimes bureaucratic obstacles get in the way; sometimes the approval of approvals is progressing slowly, especially in the historical centre (approval is needed in the Ministry of Culture) or the issues of resettlement of former residents (courts). Herein we witness an increasing pressure on statutory land-use planning. Though the national policy is aimed at attracting foreign investment and therefore softening several construction norms ${ }^{13}$, the highly formalized detailed land-use planning procedures still prevent - i. e. regulate - a rushing investment-

\footnotetext{
${ }^{10}$ The second type of public discussion is environmental assessment (an initiative of the ministry of natural resources of Belarus). It is carried out for industrial facilities, as well as near green areas and urban development projects.

${ }^{11}$ For example, the project of the detailed plan of st. Syabrovskaya and Fort No. 4 in the city of Brest were suspended for revision due to the desire of residents to preserve more green areas and to preserve rare breeds of bats and woodpeckers.

${ }^{12}$ TThe developer (or investor) for social housing and social facilities. Private investors, Belarusian or foreign, are building commercial housing, retail and office facilities.

${ }^{13}$ Many building codes, in addition to construction safety, began to be recommendatory, as many foreign companies are building: from Russia, China, Poland, Iran, Serbia, etc.
} 
driven urban development in Brest (Belarus). This is a challenging point because many post-Soviet city dwellers in Russia, Ukraine etc. suffer from and mobilize against the investment- and benefit-driven urban development today (Neugebauer et al., 2020; Mezentsev et al., 2017; Rekhviashvili et al., 2017). At the same, the planning bureaucracy does not serve per se the people.

The contested, but pre-dominant role of the national authorities in urban planning.

Finally, the example of Brest displays a particular contention for Belarusian urban planning: the tight and ambivalent nexus between the powerful and professional national authorities (ie the Ministry of Architecture and Construction) in urban planning, and the local urban planning departments that strive for more independence and responsibility. As outlined before, the Ministry develops and implements the state urban planning policy and measures for the development of investment activities. It is the customer of the master plans of regional centres (Brest, Grodno, Gomel, Vitebsk, Mogilev), which, like the general scheme of the country (GSKTO) and urban planning policy, are approved by the head of state.

On the one hand, the state centrality and professionalism in planning is favourable. It advances the promotion of new and/or relevant topics in urban planning, such as the "Green City", through state programs and subsidies incentivizing respective local initiatives. The Belarusian authorities also show perseverance about the fundamental challenge of territorial cohesion. Moreover, the central state's professionalism in planning also ensures the standards of planning, since the general planning and detailed land-use plans are centrally controlled and not a voluntary affaire of municipalities. This strong interest and the various measures of the central state in urban development contrasts with the many other post-Soviet countries where national programs and urban policies are either missing or weak. The interests and ideas of the Belarusian state authorities rather remind the German and EU policies and programs for urban and spatial development.

On the other hand, the strong role of the power vertical is perceived as constraining. More authority is needed to delegate to local authorities and residents in the field of urban planning, and today these proposals are being actively discussed at various levels. It is necessary to move not only from top to bottom (republican programs and plans) but also from bottom to top, taking into account the interests and prospects of the populated areas themselves and the opinions of residents and city authorities. This idea is anchored in EU treaties and German planning legislation as 'subsidiarity'. The Strategic Planning in Brest has shown that the local authorities are willing and owe sufficient expertise, ideas and resources to manage complex planning processes and launch dynamic processes of implementation. Due to the missing formalization of the Strategic planning instrument, it offered a chance to testify this. Though the close cooperation with the central state is indispensable and not principally questioned in Brest today, more independence and self-responsibility are envisioned. So far, however, the contradiction between the central and local state authorities constitutes a specificity of Belarusian urban planning and governance.

\section{Summary}

This latter comment contributes to the key argument of this paper, namely that the urban planning in Brest (re)produces a trajectory of gradual postSoviet transformation which is maybe unique in the FSU, but certainly too little discussed by scholars and practitioners so far. The Belarusian mode of urban planning stands out in the current post-Soviet realm that is marked by abrupt systemic breaks and a slow recovery of planning only. The Belarusian case rather displays a great continuity of formal institutions and informal routines in statutory land-use planning. The Republic of Belarus, in comparison with the countries of the former Soviet Union, has retained a professional urban planning school and the continuity of traditions, which indicates the existing fundamental professional approaches and the presence of specialized urban planning institutes such as Urban Development of the Belarusian Research and Design Institute of Regional and Urban Planning UE and UE "Minskgrad". There have been only small steps to reform the institutions and processes of urban and regional planning. One important step constitutes the introduction of mandatory civic participation in land-use planning in 2012. Still today, the central state shapes the whole 'chain of urban development' - the agenda-setting, the elaboration and control of land-use planning, the budget distribution and law enforcement.

At the same time, the current Belarusian planning shows a surprising familiarity with the planning approaches in the EU today, namely in terms of leitmotifs (contents) and principles (e.g. law enforcement and state subsidies). The Belarusian central state authorities for spatial development address essential and future-oriented topics of urban development, such as the "Green City" and "Territorial Justice", and pursue them with state programs and initiatives. These contents and measures resonate with the current EU spatial and urban agendas (Territorial Agenda 2030; EU Council, 2020) and make Belarus standing out in FSU today.

The case study of Brest also proposes that the local stakeholders importantly contribute to the (re) production of this specific trajectory of gradual transformation. The local planning department in Brest created a broad alliance with local stakeholders from science, civil society and politics and engaged actively with the benefits and constraints of the highly centralized, professional national planning authorities. The local alliance used the occasion of Strategic planning as a novel and little formalized planning instrument to link up with international experts and to test new ideas of "qualitative urban development". The Strategic planning process served as a testing ground for intensified cross-sectoral cooperation and integration within the public autho- 
rities, for new forms of citizens' involvement and an incremental approach to planning implementation. Modern practice and regulatory framework, as well as new modern leitmotifs and approaches to creating a comfortable urban environment, have been introduced. Brest succeeded to integrate informal planning into the legally binding general land-use plan and started the realization of the first urban renewal projects. In doing so, the local stakeholder alliance in Brest co-produced new opportunities for local, more autonomous urban planning in Belarus. Concerning the future, we are curious to what extent the (new) leitmotifs and planning principles will promote indeed the livability of Brest and trigger broader, incremental shifts within the Belarusian planning system.

\section{References}

Appenzeller, M. (2017). Urban planning and Governance. In I. Brade and C. Neugebauer (eds.), Urban EurasiaCities in Transformation (pp. 266-273). Berlin: DOM Publishers.

Darieva, T., \& Neugebauer, C. (2020). Urban Activism in Eastern Europe and Eurasia. Strategies and Practices. Berlin: DOM Publishers.

Dixon, M. (2010). Gazprom versus the Skyline: Spatial Displacement and Social Contention in St. Petersburg. International Journal for Urban and Regional Research, 34 (1), 35-54.

EU Council (2020). The new Leipzig Charter - The transformative power of cities for the common good. Access mode: https://www.europarl.europa.eu/thinktank/en/document.html?reference=EPRS_ATA\%282020\%29659384 (last access: 05.01.2021)

Healey, P. (1997). Collaborative Planning: Shaping Places in Fragmented Societies. London: Macmillan.

Mezentsev, K., Neugebauer, C. S., \& Mezentseva, N. (2017). Civil Society. In I. Brade and C. Neugebauer (eds.), Urban Eurasia - Cities in Transformation (pp. 274-283). Berlin: DOM Publishers.

Musterd, S., \& Murie, A. (eds.), (2010). Making Competitive Cities. Blackwell Publishers.

Neugebauer, C., \& Rekhviashvili, L. (2015). Loss and (re-)construction of public space in post-Soviet cities. International Journal of Sociology and Social Policy, 35 (7/8), doi: 10.1108/IJSSP-04-2015-0042

Neugebauer, C., Semenov, A., \& Denysenko, O. (2020). Urban activism and planning in Ukraine and Russia. In T. Darieva and C. Neugebauer (eds.), Urban Activism in Eastern Europe and Eurasia. Strategies and Practices (pp. 138-200). Berlin: DOM Publishers.

Neugebauer, C., Semenov, A., Shevtsova, I., \& Zupan, D. (2021, in press): Urban planning and civic activism. In Smyth / Morris / Semenov (eds.), Russians in Action. Indiana University Press.

Rekhviashvili, L., \& Neugebauer, C. (2017). Public spaces. In I. Brade and C. Neugebauer (eds.), Urban Eurasia - Cities in Transformation (pp. 238-252). Berlin: DOM Publishers.

Robinson, J. (2006). Ordinary cities: Between Modernity and Development. London: Routledge.

Semenov, A. (2020). Grassroots Urban Mobilisation in Russia. In T. Darieva and C. Neugebauer (eds.), Urban Activism in Eastern Europe and Eurasia. Strategies and Practices (pp. 22-29). Berlin: DOM Publishers.

Semenov, A., \& Minaeva, E. (2020). Policy transfer in urban governance: the case of strategic urban planning in Russia. Ars Administrandi, 12 (1), 120-136. doi: 10.17072/2218-9173-2020-1-120-136. [In Russian] [Семенов А. В., Минаева Э. Ю. Заимствования политических курсов в сфере городского управления: анализ стратегического городского планирования в России // Искусство управления. 2020. Том 12, № 1. С. $120-136$. doi: 10.17072/2218-9173-2020-1-120-136.]

Territorial Agenda 2030, Draft of July 2020. Access mode: https://www.territorialagenda.eu/documents.html (last access: 30.09 .2020$)$

Trumbull, N. (2010). Challenges to western participation in shaping the urban landscape of post-socialist St. Petersburg: The failure of international competitions for iconic architectural projects. Eurasian Geography and Economics, 51 (6), 788-802

Ulasiuk, N. (2013). New approaches to the design of the living environment in accordance with the priorities of the urban planning policy of the Republic of Belarus. In V. Morozov (ed.), The Architectural Heritage of the Bug Region. Problems. Research. Development trends. Collection of scientific papers of the $4^{\text {th }}$ international scientific and practical conference, Brest, 29-31 May 2013 (pp. 13-17). Brest: Brest State Technical University. [In Russian]. [Власюк Н. Н. Новые подходы к проектированию жилой среды в соответствии с приоритетами градостроительной политики Республики Беларусь. Архитектурное наследие Прибужского региона. Проблемы. Исследования. Тенденции развития : сб. науч. трудов IV межд. науч.-практ. конф., Брест, 29-31 мая 2013 г. / БрГТУ ; под общ. ред. В. Ф. Морозова. Брест: БрГТУ, 2013. С. 13-17.]

Ulasiuk, N. (2013). Planning cities with high quality environments. Architecture and Construction in Belarus, 4 (234), 28-31. [In Russian]. [Власюк Н. Н. Планирование городов с высоким качеством среды // Архитектура и строительство Беларуси. 2013. № 4 (234). С. 28-31.]

Ulasiuk, N. (2015). Brest. Five steps towards sustainable development. Architecture and Construction in Belarus, 5, 26-32. [In Russian]. [Власюк Н. Н. Брест. Пять шагов на пути к устойчивому развитию // Архитектура и строительство Беларуси. 2015. № 5. С. 26-32.] 
Ulasiuk, N. (2019). General plan of Brest. Architecture and Construction, 4, 10-13. [In Russian]. [Власюк Н. Н. Генеральный план г. Бреста // Архитектура и строительство. 2019. № 4. С. 10-13.]

Ulasiuk, N. (2019). Hygge for the city: Strategy for spatial development "Brest-2050". Architecture and Construction, 4, 6-9. [In Russian]. [Власюк Н. Н. Хюгге для города: Стратегия пространственного развития «Брест-2050» // Архитектура и строительство. 2019. № 4. С. 6-9.]

Ulasiuk, N. (2019). Strategy for spatial development Brest-2050. In A. Vabischevich (ed.), Брест. Брэст. Brest. 1000 (p. 292). Minsk: P. Brovka Belarusian Encyclopedia. C. 292. [In Russian]. [Власюк Н. Н. Стратегия пространственного развития Брест-2050 / Брест. Брэст. Brest. 1000 / сост. А. Н. Вабищевич. Минск: Беларуская Энцыклапедыя імя П. Броўкі, 2019. С. 292.] 